\title{
Integral Revision, In Semester Examination and Evaluation of Content - II Technique
}

\author{
${ }^{1}$ Ansar A. Mulla, ${ }^{2}$ Dr. Abhijeet P. Shah, ${ }^{3}$ Swapnil H. Patil \\ ${ }^{1,2,3}$ Rajarambapu Institute of Technology, Sakharale, Shivaji University Kolhapur, M.S. INDIA \\ 1. ansarmulla212@gmail.com, ${ }^{2}$ abhijeet.shah@ritindia.edu , ${ }^{3}$ swapnilh.patil@ ritindia.edu
}

\begin{abstract}
In this paper, an active learning method that was earlier proposed by the author is remodified and updated. In Integral Revision, In Semester Examination and Evaluation of Content - II Technique (IRSIEC - II Technique), it is the technique of actively learning activity by revision, examination, and assessment simultaneously is updated with the aid of the internet of things tools. This technique can be implemented at any level of education. As per the older method, In the class, groups are formed or for an individual, instructions are given to the student and subjects for each group, including a drawing sheet, to present their subject. Monitor/Teacher monitors and evaluates students. Revision, examination, and evaluation are done simultaneously. Implementation of this method takes less time and more students can participate. Each student reviews and checks the material; the student is given the opportunity to expose their learning skills. However, the updated and named IRSIEC-II allows applying for coding, mathematical like courses with aid of technical nontechnical software, internet online numerical solvers, programming solvers, and debuggers removing the limitation of usefulness for only theoretical courses. This technique has increased the student learning rate compared to the traditional method of teaching.
\end{abstract}

Keywords: IRSIEC, Active Learning, Innovative best practices, teaching-learning method, IoT.

\section{INTRODUCTION}

The change is the only permanent thing to be followed, so from traditional teacher-centric to students, centric education is transforming. The process of educating is transforming teacher-centric to a learner-centric system with an appropriate interface between teachers and learners. It is quite learned that in the education system more focus should be on students learning than teachers learning which brings to note that one - one learning. To device, it more into practice earlier IRSIEC method has been more practiced modified, remodified, and updated, which is proposed in this paper. Many researchers and educators have practice and contributed w.r.t. revising the content taught, examination/ practice test, grading based on evaluation tools, and variety of study methods; while this paper presents modifying with updating and overcoming the shortfalls in the IRSIEC technique that were observed by authors and from the feedback received from the teachers who have practiced this technique.

A system that ensures repetition and ensures the participation of all students is essential. The next step after academic delivery is the revision of content, examination, and then evaluation also getting back to the academic for the unattained learning content.

Sometimes it is customary to take a written examination after each chapter is completed. The entire lecture and evaluation must be spent separately for semester exams and evaluations. For the semester or end exams, the course teachers have to spend time in their lectures or plan the extra time for students from the regular schedule. After taking the examination, the assessor has to evaluate the paper of each student who gives more time. Evaluating answer sheets will be another task for each student. While the learning style skill of each student is different or there may a group of students that may demand a different mode of the teaching-learning process.

However, the old IRSIEC technique leads the information about the learning styles of each group and individual students after the technique has been practiced. Also, it is not suitable for each lecture to be practiced. After a quantum from a course is delivered then it will be suitable to practice. For the coding course like $\mathrm{C}, \mathrm{C}++$, etc. dealing with computer science like programs and numerically oriented courses and programs like mathematics courses it becomes less outcome activity.

If the old IRSIEC is practice with IoT tools and other aids of teaching-learning tools, the above-discussed courses will yield good teaching-learning outcomes.

Literature is surveyed and various active techniques are studied and experienced. Many researchers and academics have adopted various teaching-learning which have been learned. Few of them eat too much time and cannot be used in one or two hours of lecture. The inline literature with the earlier IRSIEC is well understood and clubbed to get better out of it and dissolve some of the shortfalls.

Nirmal Mandal [1] experienced that it could be used to improve student satisfaction and understanding of teaching and teaching undergraduate engineering units using active learning tools, techniques, methods, etc. rather than traditional distribution in the classroom. Lee and Faghhari [2] applied problem-oriented and project-oriented education that failed to add much to the project-based education and had to complete the project because of the project being 
given to the students. To complete the project, they had to educate themselves and needed a broad body of knowledge that they had acquired, and thus they had to learn. However the point was that it would take weeks, months, or more. Razzuk and Shoot [3] Focus more on design thinking, they define design thinking as an analytical and creative process that enables students to experiment, create and prototype, gather feedback and restructure a variety of features like visualization, creativity, and other problems in the $21 \mathrm{st}$ century. Godfrey et al. [4] gave a theoretical model for engineering education and advocated learning with new tools and methods. Sparks [5] discuss the characteristics of the teacher's attitude towards new learning methods and new tools that can add value to the learning process. [6] IRSIEC gives a short time active learning technique with spending two-hour lectures adding student's interest for the quantum of course but the instant learning improvement for past taught content was not elaborated and the coding and numerical course teaching-learning have to figure out. This could be done by clubbing other active learning methods and the aid of internet technology.

Active teaching is not just a technique or instrument that can help to improve learning techniques or tools by watering down learning uniqueness. For many of the techniques discussed above and the older IRSIEC the modification, the comparison, methodology, and outcome of IRSIEC-II are discussed.

\section{METHODOLOGY}

An internal examination is conducted after the completion of any course chapter/unit. The traditional method of the examination will be written or the students will be asked oral questions. This type of examination has addressed the curriculum teachers and the students have achieved success in a standard format. For example, for a specific material, can a student write some text, but can he/she connect with other topics in this chapter? The answer is probably No. This IREC method shows that more students or group members are learning their preferences. This method is effective for any class/semester of engineering students.

The detailed methodology for the older IRSIEC is shown in the flowchart fo Fig. 1. While the updated one IRSIEC-II is more elaborated and the updates have been made to notice. The following steps have been add taken to implement this method.

\section{A. Group Formation/Individual Student}

The student groups could be formed irrespective of gender; preferably, a heterogeneous group with a mix of boy and girl students and fast and slow learners is advocated. As far as possible, the groups should be formed with an equal number of students. In the case of the odd number of student's strength, the students are equally divided into groups and the remaining students could be allocated randomly to any of the groups. However, for the courses in the case, where the content/title or task can be given for an individual student, the individual student-teacher activity will be performed, here more than one mentor will boost the activity.

\section{B. Drawing Sheets Distribution}

For exploring their responses answers to the given subject, each group should be provided size 2 size or large ( 1 or 0 ) drawing sheets. The sheets should be empty and useable on both sides. Students can stick to these sheets and the following steps are taken to implement this method. Resources such as program-specific software, computer laboratory, Wi-Fi/internet facility and access, etc. within campus vicinity should be made available. These resources will be helpful for coding and numerical/mathematical based courses.

\section{Topic Content to each group/Individual}

The content on which this method is to be applied is divided among the chapters, units, or sections in the numbers the same as the number of groups formed. However, topic to an individual also can be given w.r.t. special course. Each group is assigned a group number and the topic. In this way, complete course content is divided into groups or to the individual student.

D. Instructions to the groups/Individuals

The groups are formed, drawing sheets are distributed and topics to each group are given, students should be asked to write group number on the left column (of width 10-12cm), the title of task/content given, Serial No., Roll No, Student Name, Signature ( for attendance \& acknowledgment), Write Possible questionaries for a given content, Use of both sides of a sheet, All efforts for better of content and representation, Use of resources, Technical, Non-Technical software tools, internet tools. e.g. AUTOCAD, Math solvers, online Java debugger, etc. Student information could be mention as per Table 1 .

Table 1. Student Details Table

\begin{tabular}{|c|c|c|c|}
\hline \multicolumn{3}{|c|}{ Group No: - 00 } \\
\hline Sr. No. & Roll No. & Student Name & Signature. \\
\hline
\end{tabular}

Students to be asked to create a possible questionnaire for the given content so that questions in different directions can be drawn, students can learn the thinking process and the requirements of the content questionnaire. Students are informed about total marks distribution (100\% Total marks $=50 \%$ Individual marks $+50 \%$ Group marks)

A general guideline for evaluation -to credit appreciate students for their participation in the activity is as shown in Table 2.

Table 2: Guidelines (Rubric) for Group and Individual evaluation/ assessment

\begin{tabular}{|l|l|l|l|l|}
\hline Group & Level 1 (1-4) & Level 2 (5-7) & Level 3 (8-10) & Expected Outcomes \\
\hline
\end{tabular}




\begin{tabular}{|c|c|c|c|c|}
\hline $\begin{array}{l}\text { Evaluation } \\
(\mathbf{5 0 \%})\end{array}$ & & & & \\
\hline $\begin{array}{l}\text { Content } \\
\text { representation of } \\
\text { a sheet of each } \\
\text { group }\end{array}$ & $\begin{array}{l}\text { The only information } \\
\text { in the form of text as } \\
\text { copied from resources } \\
\text { is on sheet. }\end{array}$ & $\begin{array}{l}\text { The given content to a } \\
\text { group is merely put on a } \\
\text { sheet with different } \\
\text { representations such as } \\
\text { text, tree diagram, } \\
\text { flowchart figure, etc. but } \\
\text { lack of correlation with the } \\
\text { sub-content of the given } \\
\text { topic. }\end{array}$ & $\begin{array}{l}\text { At a glance, the content } \\
\text { on the sheet speaks } \\
\text { sub-content } \\
\text { fundamentals and } \\
\text { correlation with each } \\
\text { other, possible } \\
\text { quaternary with all } \\
\text { level varieties etc. }\end{array}$ & $\begin{array}{l}\text { Hidden way of } \\
\text { expressing knowledge } \\
\text { of students is } \\
\text { observed and sparked. }\end{array}$ \\
\hline $\begin{array}{l}\text { Team work, } \\
\text { effort and } \\
\text { coordination }\end{array}$ & $\begin{array}{l}\text { Only one or two of the } \\
\text { team members are } \\
\text { taking effort and others } \\
\text { do not have any } \\
\text { contribution. }\end{array}$ & $\begin{array}{l}50 \% \text { of the team members } \\
\text { are taking effort to develop } \\
\text { their sheet and other are } \\
\text { with negligence attitude. }\end{array}$ & $\begin{array}{l}\text { All the team members } \\
\text { are taking effort to } \\
\text { develop their sheet as } \\
\text { knowledge full as they } \\
\text { can. }\end{array}$ & $\begin{array}{l}\text { Students communicate } \\
\text { the sub content/topic } \\
\text { with each other in their } \\
\text { group. }\end{array}$ \\
\hline $\begin{array}{l}\text { Presentation of } \\
\text { the whole sheet } \\
\text { to an audience }\end{array}$ & $\begin{array}{l}\text { Only one group } \\
\text { member is aware of } \\
\text { whole presentation and } \\
\text { other members have } \\
\text { very less contribution. }\end{array}$ & $\begin{array}{l}\text { Not all but few of the } \\
\text { group members are aware } \\
\text { of whole presentation and } \\
\text { contribute in the } \\
\text { presentation }\end{array}$ & $\begin{array}{l}\text { Each member of group } \\
\text { is aware of whole } \\
\text { presentation and } \\
\text { contribute equally in } \\
\text { the delivery of } \\
\text { presentation. }\end{array}$ & 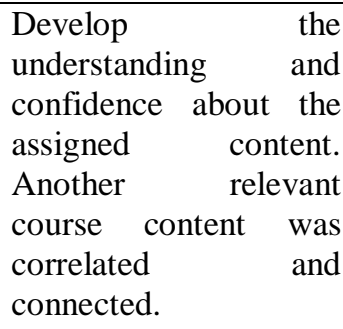 \\
\hline $\begin{array}{l}\text { Questions and } \\
\text { Answers }\end{array}$ & $\begin{array}{l}\text { Less than } 50 \% \text { of the } \\
\text { questions posed by the } \\
\text { audience were answer } \\
\text { effectively by the } \\
\text { group members. }\end{array}$ & $\begin{array}{l}\text { Between } 50-80 \% \text { of the } \\
\text { questions posed by the } \\
\text { audience was answered } \\
\text { effectively by the group } \\
\text { members. }\end{array}$ & $\begin{array}{l}\text { More than } 80 \% \text { of } \\
\text { questions posed by the } \\
\text { audience was answered } \\
\text { effectively by the } \\
\text { group members. }\end{array}$ & $\begin{array}{l}\text { Instil \& demonstrate } \\
\text { confidence } \\
\text { knowledge to and } \\
\text { audience. }\end{array}$ \\
\hline $\begin{array}{l}\text { Innovation and } \\
\text { Creativity }\end{array}$ & $\begin{array}{l}\text { No creativity in } \\
\text { creating sheet by the } \\
\text { group members. }\end{array}$ & $\begin{array}{l}\text { Some creativity } \\
\text { presentation of their } \\
\text { content on sheet is done by } \\
\text { the group members. }\end{array}$ & $\begin{array}{l}\text { All the contents have } \\
\text { been reflected with } \\
\text { creative thought } \\
\text { process and with best } \\
\text { of each student } \\
\text { members ideas. }\end{array}$ & $\begin{array}{l}\text { Students appreciate } \\
\text { role of innovation and } \\
\text { creativity during } \\
\text { collecting, assembling } \\
\text { and presenting the } \\
\text { information to the } \\
\text { audience. }\end{array}$ \\
\hline $\begin{array}{l}\text { Individual } \\
\text { Evaluation } \\
(\mathbf{5 0 \%})\end{array}$ & Level 1 & Level 2 (5-7) & Level 3 (8-10) & Expected Outcomes \\
\hline $\begin{array}{l}\text { Individual } \\
\text { student's } \\
\text { contribution. }\end{array}$ & $\begin{array}{l}\text { Very less individual } \\
\text { contribution } \\
\text { observed. }\end{array}$ & $\begin{array}{l}\text { Moderate individual } \\
\text { contribution in developing } \\
\text { sheet and during the } \\
\text { presentation. }\end{array}$ & $\begin{array}{l}\text { Leading the team in } \\
\text { developing their sheet } \\
\text { and presentation. }\end{array}$ & $\begin{array}{l}\text { Individual students } \\
\text { learning techniques } \\
\text { (e.g. visual - Diagrams, } \\
\text { Connectivity- Arrow } \\
\text { connections, Step by } \\
\text { Steps learning Flow } \\
\text { chart) are reflected. }\end{array}$ \\
\hline $\begin{array}{l}\text { Effective use of } \\
\text { individual } \\
\text { student's skill to } \\
\text { prepare sheet. }\end{array}$ & $\begin{array}{l}\text { No specific method/ } \\
\text { skill used to develop } \\
\text { the sheet is evident. }\end{array}$ & $\begin{array}{l}\text { Demonstrates efforts to use } \\
\text { certain skills viz. concept } \\
\text { diagrams, figures, CAD } \\
\text { model etc. for preparation } \\
\text { of sheet. }\end{array}$ & $\begin{array}{l}\text { Uses innovative skills } \\
\text { and demonstrates } \\
\text { mastery or uniqueness } \\
\text { while developing the } \\
\text { sheet. }\end{array}$ & $\begin{array}{l}\text { Exposure to his/her } \\
\text { skill sets for learning } \\
\text { approach. }\end{array}$ \\
\hline $\begin{array}{l}\text { Ability to lead } \\
\text { and coordinate } \\
\text { the group }\end{array}$ & $\begin{array}{l}\text { No leadership and } \\
\text { coordination ability } \\
\text { demonstrated }\end{array}$ & $\begin{array}{l}\text { Reasonable leadership and } \\
\text { coordination } \\
\text { demonstrated. }\end{array}$ & $\begin{array}{l}\text { Leadership } \\
\text { coordination } \\
\text { demonstrated } \\
\text { convincing }\end{array}$ & $\begin{array}{l}\text { Demonstrate the ability } \\
\text { to lead the group. }\end{array}$ \\
\hline Effectiveness of & Demonstrates & Demonstrates reasonable & Demonstrates & Demonstrate \\
\hline
\end{tabular}




\begin{tabular}{|c|c|c|c|c|}
\hline $\begin{array}{l}\text { individual } \\
\text { presentation }\end{array}$ & $\begin{array}{l}\text { understanding of the } \\
\text { content and casual } \\
\text { attitude } \\
\text { presentation. }\end{array}$ & $\begin{array}{l}\text { understanding of the } \\
\text { content but without } \\
\text { confidence. }\end{array}$ & $\begin{array}{l}\text { understanding of the } \\
\text { content and presents } \\
\text { confidently. }\end{array}$ & $\begin{array}{l}\text { presentation skills and } \\
\text { knowledge of the } \\
\text { content. }\end{array}$ \\
\hline $\begin{array}{l}\text { Ability to } \\
\text { answer the } \\
\text { questions posed } \\
\text { by the audience. }\end{array}$ & $\begin{array}{l}\text { Cannot answer the } \\
\text { question/s posed by the } \\
\text { audience, or show } \\
\text { willingness to answer } \\
\text { the question/s or } \\
\text { answer the question/s } \\
\text { without being } \\
\text { confident. }\end{array}$ & $\begin{array}{l}\text { Answers a few questions } \\
\text { but cannot elaborate on the } \\
\text { answer. }\end{array}$ & $\begin{array}{ll}\text { Answers nearly } & \text { all } \\
\text { questions with } & \text { proper } \\
\text { explanation } & \text { and } \\
\text { justification. } & \end{array}$ & $\begin{array}{l}\text { Respond to the } \\
\text { questions } \\
\text { demonstrating deep } \\
\text { understanding and } \\
\text { conviction. }\end{array}$ \\
\hline
\end{tabular}

\section{E. Teacher/mentor Role}

Teachers should monitor and monitor each group, assess whether all students are participating, the overall score of $50 \%$ for the performance of individual students. $50 \%$ marks given to groups after completion of the sheet as per the assessment table 3 below. Group marks will contribute to their sheet work and group presentation. If there is individual students' activity, then the $100 \%$ evaluation w.r.t individual assessment guidelines

Table 3. Assessment Table

\begin{tabular}{|c|c|c|c|c|}
\hline \multicolumn{5}{|c|}{ Group No: - 00 } \\
\hline \multirow{2}{|c|}{ Student Details } & \multicolumn{3}{c|}{ Marks } \\
\hline Roll No. & Student Name & $\begin{array}{c}\text { Individual } \\
\text { Marks (50\%) }\end{array}$ & $\begin{array}{l}\text { Group } \\
\text { Marks } \\
(50 \%)\end{array}$ & $\begin{array}{c}\text { Total } \\
\text { Marks } \\
(100 \%)\end{array}$ \\
\hline
\end{tabular}

Finally, each group/individual will be asked to present their content to other groups in front of all the audience.

A group will stand in front of all other groups and each member will contribute to explain/present their drawing sheet. The time distribution is in Table 4.

Table 4. Time distribution for deploying of this Method

\begin{tabular}{|l|c|}
\hline \multicolumn{1}{|c|}{ Steps for deploying IRSIEC-II method } & $\begin{array}{c}\text { Time in } \\
\text { minutes }\end{array}$ \\
\hline Group formation & 05 \\
\hline Drawing sheets distribution to each group & 02 \\
\hline Topics/Content to each group & 02 \\
\hline Instruction to groups by the course teacher & 10 \\
\hline
\end{tabular}

\begin{tabular}{|l|c|}
\hline $\begin{array}{l}\text { Preparation of sheet for a given topic by the team } \\
\text { (Simultaneously group and individual } \\
\text { evaluation). }\end{array}$ & 45 \\
\hline $\begin{array}{l}\text { Presentation \& QA (by each group on stage) } \\
\text { (Simultaneously group and individual } \\
\text { evaluation) }\end{array}$ & $\begin{array}{c}(5+2) * 8=56 \\
\text { For eight } \\
\text { group }\end{array}$ \\
\hline \multicolumn{1}{|c|}{ Total Time Required } & $120 \mathrm{~min}$ \\
\hline
\end{tabular}

According to the number of groups and members of each group, the time to implement this method may vary.

IRSIEC-II illustration - This method is implemented for the third year B. Tech. Automobile class, second and thirdyear students of Polytechnique level

Flow Chart (Fig 1,2 Flowchart for IRSIEC Implementation) offers steps to use IRSIEC for any course and class. As mentioned earlier, while presenting this course at Rajarambapu Institute of Technology in Sakharale, the IRSIEC method was implemented for the second year, the third year of the students of automobile engineering.at degree level and also to mechanical engineering to Polytechnique level. Flow Chart (Fig 2 Flowchart for IRSIEC-II Implementation shows the solution for implementing this active learning method for coding like and mathematical, calculative courses

After the successful implementation of this method, the feedback was received from the students and the students were found to be enthusiastic and satisfied with the challenge. Students were interested in doing this instead of the traditional method and were expected to repeat it for other parts of the curriculum. 


\section{Group Formation.}

- Heterogeneous groups to be formed - equal members and equal no. of groups

\section{Drawing Sheets Distribution.}

- Drawing sheet of minimum of A2 size or bigger size (A1 or A0) should be given to each group OR Ask Student to get by them self.

\section{Topics/Content to each groups.}

- Bifurcate Chapter/Unit or Section in a Course or Complete Course in same number as number of groups.

\section{Instruction to groups.}

- Write Group Number on left column (of width 10-12 cm)

- Write Title of Content given.

- Serial No, Roll No, Student Name, Signature (for attendance \& Acknowledgement)

- Possible Questionnaries for given content.

- Use both side of sheet, All efforts to work for better content \& representation.

- Use any source, but mention reference at respective content

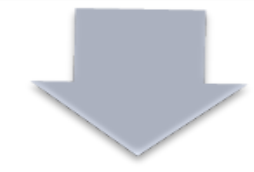

\section{Teacher Role}

- Observe each group, every students contribution,

- Give marks for $50 \%$ of total marks for individual students.

- $50 \%$ marks will be given after completion of sheet \& Presentations to the groups.

- Total $\operatorname{Marks}(100 \%)=$ Individual $(50 \%)+$ Group(50\%)

Fig. 1 Flowchart for IRSIEC implementation [6] 


\section{Group Formation/Individual Student.}

- Heterogeneous groups of equal students with same number of groups to be formed

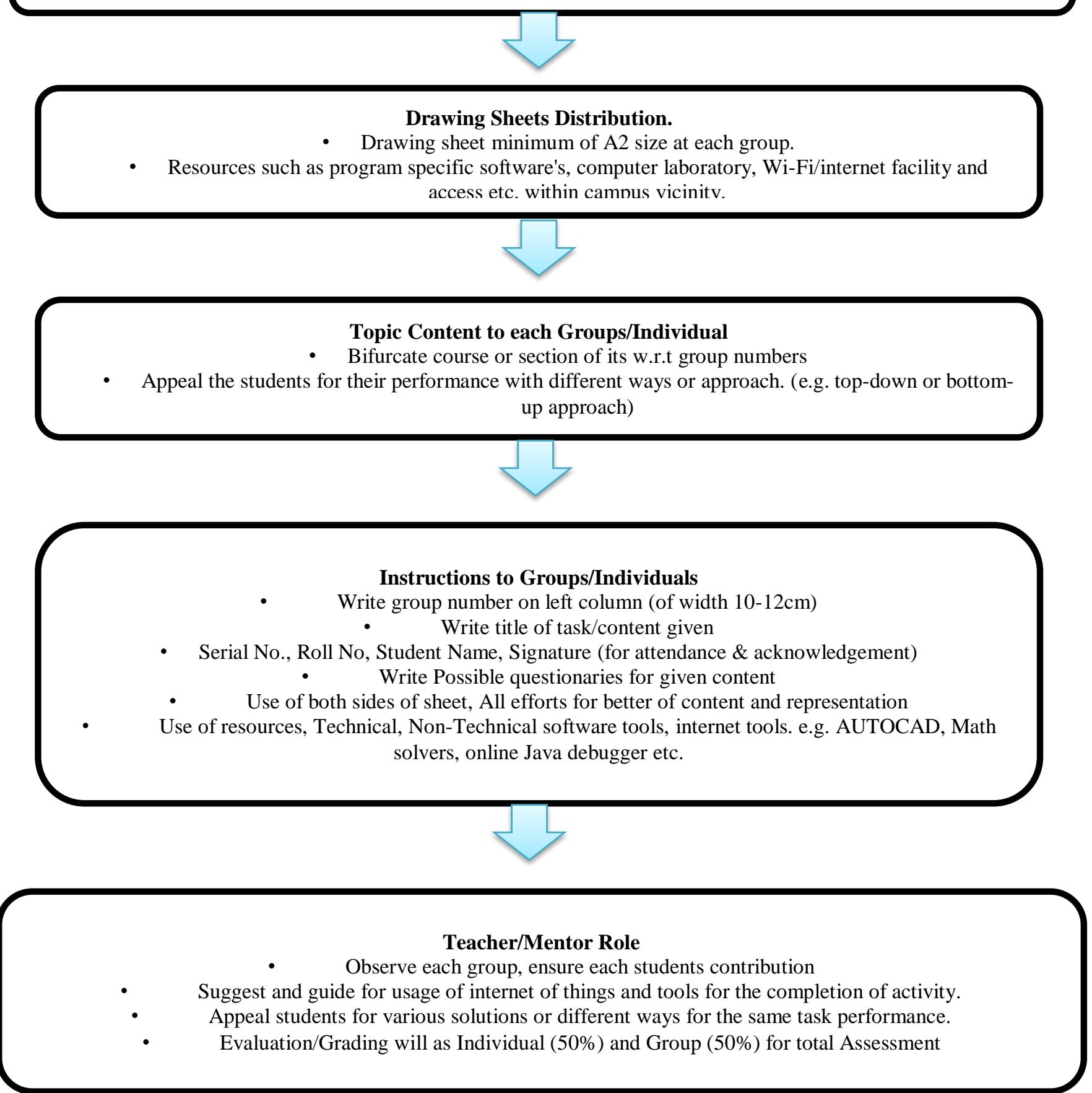

Fig. 2 Flowchart for IRSIEC - II implementation

\section{F. Results and Discussion}

Application of this technique, the authors believe, shall add value to the learning quotient of the students by increasing self-interest and active engagement with the course content.
This technique is easy to implement to enhance the teaching process; Content can be reviewed and evaluated simultaneously.

After completing this method, it appears that the hidden way of expressing the knowledge of the students was followed and fueled. Students were interacting with each other in their group. They were using software like 
MATLAB to solve matrix problems, online coding solvers/debugger platforms for their codes. The content of the course is connected and connected. Students were looking for different sources of class notes, books, e-books, PowerPoint presentations, videos on the Internet, etc. Personal student learning techniques (e.g. visual-diagram, connectivity-arrow connection, step by a step-by-step flow chart, different ways of solving same mathematical problems, optimized codes for programming, etc.) are effectively used.

According to the authors, the use of this technique will add value to the student's learning and increase active participation in academics.

\section{Acknowledgments}

I would like to acknowledge my sincere gratitude towards my department and the Institute for allowing me to devise and implement various active learning techniques as a part of the course delivery in academics.

\section{Conclusion}

The authors have suggested their own improved active learning technique for engineering classes called IRSIEC-II, which combines delivery and evaluation and takes about two hours to implement. The details of the engagement are summarized in this work. Teachers are getting good feedback from the students for engagement and learning. This integrated learning experience can make students feel connected to all the ups and downs of the unit or course. Students are taking responsibility for their education, which is a sign of any active learning success. The objective of the technique is to actively work in the classroom and present their education learning. This method can be useful for any engineering theory, coding, mathematical course.

\section{References}

[1] Nirmal Mandal (2017), "Student satisfaction - What it means to teaching and learning of undergraduate engineering units", International Journal of Mechanical Engineering Education, (030641901774199), (2017).

[2] Mingxin Li and Ardeshir Faghri (2016), "Applying Problem-Oriented and Project-Based Learning in a Transportation Engineering Course", Journal of Professional Issues in Engineering Education and Practice, 142, 3, (04016002), (2016).

[3] Rim Razzouk and Valerie Shute, (2012) "What Is Design Thinking and Why Is It Important?" Review of Educational Research, 82, 3, (330), (2012).

[4] Godfrey, E. (2003). "A theoretical model of the engineering education culture: A tool for change." American Society for Engineering Education Annual Conference Exposition, American Society for Engineering Education (ASEE), Washington, DC.

[5] Sparks, G. (1988), "Teacher attitudes towards change and subsequent improvements in classroom teaching." J. Educ. Psychol., 80(1), 111-117.

[6] Ansar A. Mulla, Satyajit R. Patil, Taufiq Mulla, (2019) "IRSIEC Technique - Integral Revision, In Semester
Examination and Evaluation of Content/Course", Journal of Engineering Education Transformations, Volume 32, No. 4, April 2019, ISSN 2349-2473, eISSN 2394-1707. 